Original Contribution

\title{
THE ROLE OF AVIAN METAPENUMOVIRUS IN RESPIRATORY COMPLEX DISEASE CIRCULATING IN BROILERS IN NORTHERN IRAN
}

\author{
S. Seifi ${ }^{1 *}$, Z. Boroomand ${ }^{2}$ \\ ${ }^{1}$ Department of Clinical Sciences, Faculty of Veterinary Medicine, Amol University of Special Modern \\ Technologies, Amol, Iran \\ ${ }^{2}$ Department of Clinical Sciences, Faculty of Veterinary Medicine, Shahid Chamran University, \\ Ahvaz, Iran
}

\begin{abstract}
Avian metapneumovirus (aMPV) is the etiologic agent of a respiratory disease of poultry. In a 6 months period from October 2012 to March 2013, broiler flocks with respiratory signs are examined in northern Iran. The purpose of the given research was to define presence of antibodies of the birds' avian metapneumovirus among broilers and detection of virus. Birds were not vaccinated against this virus. Total 525 blood samples and trachea/nasal turbinates swabs were obtained from 35 commercial broiler flocks and pooled (5 swabs/pool), then RT-PCR method was done on these 105 pooled samples. Presence of antibodies against the bird's metapneumovirus in each serum sample has been tested by method of immune-enzyme analysis. $10(28.5 \%)$ flocks had positive antibodies. Of the 35 flocks, 8 were positive by RT-PCR with Nd/Nx primers (23\%). This is the first report of APV infection in northern Iran. Vaccination programs should be adjusted to include the APV vaccine to aid in the control of this respiratory disease in the Iranian poultry industry.
\end{abstract}

Key words: Avian metapneumovirus (aMPV), Broilers, Respiratory complex, Iran.

\section{INTRODUCTION}

Infections of the respiratory tract have significant economical impact on poultry production worldwide. Various pathogens have been known as causing respiratory diseases, acting either in a primary or secondary role. Avian metapneumovirus (aMPV) is a respiratory virus that infects a range of avian hosts, including chickens and turkeys. aMPV is a member of the subfamily Pneumovirinae under the family Paramyxoviridae (1). Based on genetic and antigenic properties, aMPV can be classified into 4 subgroups: A, B, C, and D. While subtype A and B viruses are mainly prevalent in Europe $(2,3)$, Asian countries (4), subtype $\mathrm{C}$ is most prevalent in the United States (5). An additional subtype $\mathrm{D}$ has been first reported in France (6). aMPV causes turkey rhinotracheitis (TRT), an acute respiratory tract infection in turkeys of all ages. The virus is also associated with swollen head syndrome (SHS) in

*Correspondence to: Saeed Seifi, $24^{\text {th }}$ Aftab, Emam Khomeini Street, Amol, Iran, PO Box 46168-49767, s.seifi@ausmt.ac.ir broilers and broiler breeders (7) and egg production losses in layers (8). In recent years, outbreaks of respiratory disease have been increased in poultry farms in Iran. Clinical signs of disease are including tracheal rales, nasal and ocular discharge, and swelling of the face and head which followed by high mortality. Studies showed that viral and bacterial factors are involved in causing of this condition (9-11), thus, clinicians have used the term of "respiratory complex" for this condition. The aim of this study was to investigate of aMPV in broilers farms with respiratory distress.

\section{MATERIAL AND METHODS SAMPLE COLLECTION}

Thirty-five commercial broiler flocks suffering from respiratory disease, in the north of Iran, were examined over a 6 months period from October 2012 to March 2013. Fifteen serum samples and trachea/nasal turbinates swabs were obtained from birds per flock and pooled (5 serums/tube and 5 swabs/pool). Swabs and serums were stored in cool boxes at $4{ }^{\circ} \mathrm{C}$ and transported to the laboratory within two days. 
All the flocks were between 5-7 wks of age and were not vaccinated against aMPV.

\section{ENZYME-LINKED IMMUNOSORBENT ASSAY (ELISA)}

Specific aMPV-antibodies in serum samples were detected by a commercially available enzyme-linked immunosorbent assay (ELISA) system (Avian Rhinotracheitis Antibody Test $\mathrm{Kit}^{\odot}$, CK 120, BioChek, Netherlands) according to the manufacturer's recommendation. Briefly, samples were diluted in a 1/500 ratio and the OD was measured on an ELISA microplate reader (SFRI IRE96, France) at $405 \mathrm{~nm}$. Results were determined by calculating the sample to positive (S/P) ratio. Samples with $\mathrm{S} / \mathrm{P}$ ratios of 0.5 or greater (titres higher than 1656) are considered as aMPV antibody positive.

\section{DETECTION OF THE AMPV GENOME BY RT-PCR}

\section{RNA EXTRACTION}

Extraction of RNA was performed on the pooled material for swabs from each flock with RNX TM_Plus reagent (CinnaGen, Iran) according to the manufacturer's procedure. Swabs were placed in PBS and were scraped on the side of the tube to facilitate removal of contents from the swab head. $1 \mathrm{ml}$ of RNX solution was added to $100 \mathrm{mg}$ of each pooled swabs contents, then $200 \mu 1$ of chloroform were add to the mixture. After centrifugating the samples at $12000 \mathrm{rpm}$ for $15 \mathrm{~min}$., the aqueous phase were transferred to another tube. RNA was precipitated with addition of equal volume of isopropanol. After washing the sediment with $75 \%$ ethanol, it was eluted in $50 \mu \mathrm{l}$ of distilled water and stored at -70 ${ }^{\circ} \mathrm{C}$ until used.
REVERSE TRANSCRIPTION-POLYMERASE CHAIN REACTION

The reverse transcription (RT) reaction was performed with RevertAid ${ }^{\mathrm{TM}}$ First Strand cDNA Synthesis Kit (Fermentas, Lithuania) according to the manufacturer's recommendation. Then the PCR was performed using primers, Nd (5'-AGC AGG ATG GAG AGC CTC TTT G-3') and Nx (5'-CAT GGC CCA TTA ACA TGT T-3'). PCR was performed to amplify a $115 \mathrm{bp}$ fragment of the $\mathrm{N}$ protein gene of the aMPV, using the AccuPower PCR PreMix kit (BioNeer, South Korea) containing Taq DNA polymerase $1 \mu \mathrm{L}$, each dNTP(dATP, dCTP, dGTP, dTTP) $250 \mu \mathrm{M}$, Tris- $\mathrm{HCl}$ (Ph:9.0) $10 \mathrm{mM}, \mathrm{KCl} 40 \mathrm{mM}$ and $\mathrm{MgCl} 21.5 \mathrm{mM}$. Amplification was performed using Eppendorf thermal cycler for 35 cycles of pre denaturation at $94 \circ \mathrm{C}$ for $15 \mathrm{~min}$, denaturation at $94{ }^{\circ} \mathrm{C}$ for $20 \mathrm{sec}$., annealing at 51 ${ }^{\circ} \mathrm{C}$ for $45 \mathrm{sec}$., extension at $72{ }^{\circ} \mathrm{C}$ for 45 seconds and finally at $72{ }^{\circ} \mathrm{C}$ was performed with a 10 minute final extension phases. The products were analyzed in a $1 \%$ agarose gel containing ethidium bromide, using an ultraviolet transilluminator.

\section{RESULTS AND DISCUSSION}

ELISA was used to detect seroprevalence to avian metapneumovirus in 525 sera collected from 35 broiler flocks aged 5-7 weeks. Results showed that $28.5 \%$ of the tested samples contained APV antibodies, while $71.5 \%$ were negative (Table 1). The RT-PCR technique amplified the $115 \mathrm{bp}$ fragment from clinical samples. Of the 35 flocks, 8 were positive by RT-PCR with $\mathrm{Nd} / \mathrm{Nx}$ primers (23\%). positive control resulted in the expected fragment, whereas no amplification was found in the reaction corresponding to the negative control (Figure 1).

Table 1. Avian metapneumovirus ELISA results in broiler flocks (Northern Iran)

\begin{tabular}{ccc}
\hline Number & Negative & Positive \\
\hline 35 & $25(71.5 \%)$ & $10(28.5 \%)$ \\
\hline
\end{tabular}

The clinical diseases that may result from avian metapneumovirus (aMPV) infections of turkeys or chickens have been termed turkey rhinotracheitis (TRT), avian pneumovirus infection of turkeys (APV), swollen head syndrome (SHS), and avian rhinotracheitis (ART), based on clinical signs and lesions. However, these clinical signs and lesions are not specific for aMPV infections and can be confused with disease resulting from mono- or co-infections with other respiratory pathogens.

Nevertheless, it is now universally accepted that the conditions referred to as TRT, SHS, or ART can occur as a result of infection with aMPV. The more severe form of associated disease probably results from dual or secondary infection with other organisms, and for SHS, the 
characteristic swollen head appears as a result of co-infection with secondary adventitious bacteria, usually Escherichia coli (1). For the first time in northern regions of Iran, detection of aMPV and investigation of its specific antibodies in broiler farms concerning respiratory distress has been revealed. Because all studied flocks were between 5-7 weeks of age at sampling time and none was vaccinated, results suggest field exposure of these flocks to aMPV and exclude the possibility that the detected antibodies were due to maternal antibodies or vaccination. These findings confirm that aMPV is endemic in Iranian broiler flocks. Seroprevalence of APV has been found in other countries in the region (12-14).

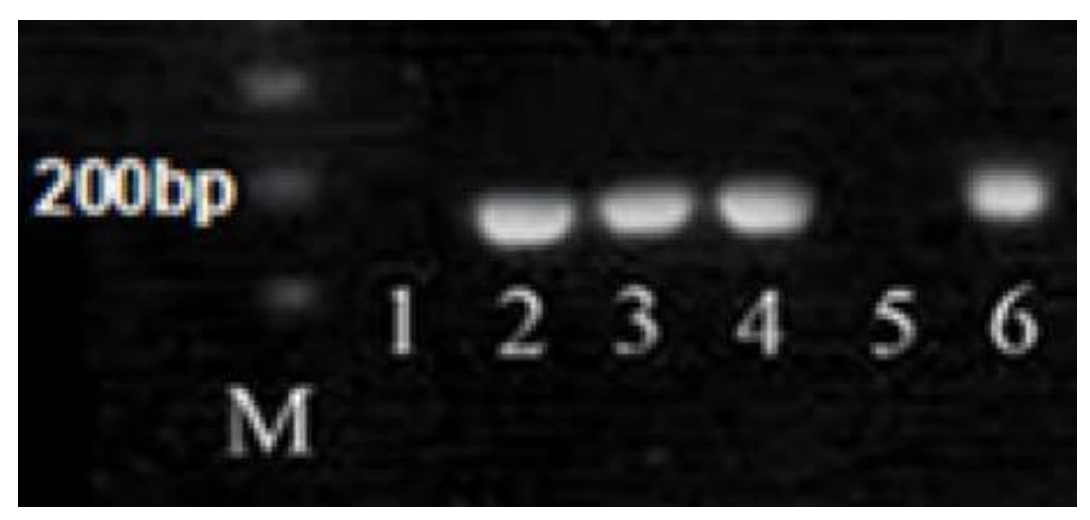

Figure 1. RT-PCR of Iranian strains of aMPV. lane 1, negative control; lanes 2, 3 and 4 positive field strains; lane 5, negative samples; lane 6, positive control (vaccine strain); M, molecular size maker (100 bp)

The results showed that $23 \%$ broiler flocks were serologically positive for aMPV, which supports previous researchers' findings in Iran $(15,16)$. Although no bacterial examination was done on positive samples, but it seems that aMPV is responsible for these symptoms. On the other hand, role of environmental factors and bacterial infections are very important in severity of diseases condition.

In 2007, researchers have attempted to examine the aMPV in commercial laying flocks with no history of vaccination. All positive samples were examined for of infectious bronchitis virus (IBV), Laryngotracheitis (LT), Newcastle disease (ND) and Mycoplasma gallisepticum (MG) studied and only aMPV was detected (17). The aMPV infection is associated with high morbidity, and mortality may rise to 50 percent with the involvement of secondary agents such as Mycoplasma species, Bordetella avium and Ornithobacterium rhinotracheale (18).

According to the previous studies, detection of anti-APV antibodies among broilers was significantly lower than among layer and broiler breeder flocks. This may be due to the short life span of broiler flocks and the time of blood sample collection, which was at the acute stage of the respiratory disease $(14,16)$.
The signs and lesions observed in the field and the detection of aMPV by RT-PCR, suggest that aMPV might have been responsible for the disease outbreaks. However, as the clinical signs observed could have been produced by other pathogens, differential diagnosis with other respiratory agents was performed (data not shown). NDV and avian influenza virus (AIV) were not detected in any of the flocks. According to results, we suggest that the aMPV detected in this study might have been responsible for the respiratory disease in these flocks. Of course, as mentioned, some other factors such as IBV and MG can contribute to create of clinical symptoms.

Homayounfar et al. (15) in a study to detection of aMPV in poultry farms in northwest Iran reported that the nucleotide sequence of the gene $\mathrm{G}$ indicates that the positive samples belonged to the subtype $B$ of virus. Phylogenetic tree evaluation of Iranian aMPV filed strains and vaccinal strain showed that they are located in separated branches. Gharaibeh and Algharaibeh (14) and Banet Noach et al. (19), showed APV subtype B is circulating in Jordanian and Israeli poultry, respectively. It seems that serotype B is dominant in Middle East.

In chickens, the role of APV as a primary pathogen is less well established, although the 
virus is commonly associated with SHS. APV infection is more severe when accompanied by secondary bacterial infection, as the virus tends to invade more internal organs and the virus titers are higher. The rate of spread and virulence vary greatly, but simultaneous infections with Pasteurella spp., Bordetella avium, E. coli, Newcastle disease virus or Ornithobacterium rhinotracheale exacerbates disease $(20,21)$. Loss of cilia on the epithelial surface of the upper respiratory tract can be associated with other infectious agents and may enhance infection with avian metapneumo virus, allowing deeper penetration of the virus into the respiratory tract (22). Experimentally, infected birds often show recognizable signs of rhinotracheitis, but these are milder than those seen in the field (23). Chickens show, at most, only mild respiratory disease in laboratory infections and nasal mucus may often only be discernible after light squeezing behind the nostrils. Presumably, the difference in pathogenicity between laboratory and field infections is related to the conditions under which the birds are kept and the presence or absence of exacerbative organisms. In laboratory studies concurrent infection of turkey poults with aMPV and respiratory bacteria, such as E coli, Bordetella avium and Riemerella anatipestifer $(22,24)$ and low virulent (lentogenic) Newcastle disease virus (25), significantly exacerbate and prolong clinical signs and morbidity.

\section{CONCLUSIONS}

Further studies such as virus isolation and molecular techniques in order to characterization of current subtypes in the field are useful. These data will suggest review of the vaccination against APV in broiler flocks in Iran.

\section{REFERENCES}

1. Jones, R. C, S. Rautenschlein. Avian Metapneumovirus. In: Swayne DE, Glisson JR, McDougald LR, Nolan LK, Suarez DL, Nair V (eds), Diseases of Poultry. $13^{\text {th }}$ ed., Ames, Iowa, USA, pp 112-120, 2013.

2. Collins, M. S., R. E. Gough, D. J. Alexander. Antigenic differentiation of avian pneumovirus isolates using polyclonal antisera and mouse monoclonal antibodies. Avian Pathol, 22: 469-479, 1993.

3. Hafez, H. M., M. Hess, C. Prusas, C. J. Naylor, D, Cavanagh. Presence of avian Pneumovirus type A in continental Europe during the 1980s. Vet Med, 47: 629-633, 2000 .
4. Mase, M., S. K. Yamaguchi, T. Tsukamoto, K. Imada, K. Imai, Nakamura. Presence of Avian Pneumovirus Subtypes A and B in Japan. Avian Dis, 47: 481-484, 2003.

5. Shin H. J., Cameron K. T., Jacobs J. A., Turpin E. A., Halvorson D. A., Goyal S. M., Nagaraja K. V., Kumar M. C., Lauer D. C., Seal B. S., M. K. Njenga. Molecular epidemiology of subgroup $\mathrm{C}$ avian pneumovirus isolated in the United States and comparison with Subgroup A and B virus. $J$ Clin Microbiol, 40: 1687-1693, 2002.

6. Toquin D., Bayon-Auboyr M. H., Eterradossi N., Morin H., V. Jestin. Isolation of pneumovirus from Muscovy duck. Vet Rec. 145: 680, 1999.

7. Gough RE, Manvell RJ, Drury SEN, Pearson DB (1994): Isolation of an avian pneumovirus from broiler chickens. Vet Rec, 134, 353-354.

8. Sugiyama M, Koimaru H, Shiba M, Ono E, Nagata T, Ito $\mathrm{T}$ (2006): Drop in egg production in chickens by experimental infection with avian Metapneumovirus strain PLE8T1 derived from swollen head syndrome and the application to evaluate vaccine. J Vet Med Sci, 68, 783-787.

9. Hadipour MM, Habibi GH, Golchin P, Hadipourfard MR, Shayanpour N (2011): The role of avian influenza, Newcastle disease and infectious bronchitis viruses during the respiratory disease outbreak in commercial broiler farms of Iran. Int J Anim Vet Adv, 3, 69-72.

10.Poorbaghi SL, Mohammadi A, Asasi K (2012): Molecular detection of avian Infectious bronchitis virus serotypes from clinically suspected broiler chicken flocks in Fars province of Iran. Pak Vet J, 32, 93-96.

11.Seifi S, Asasi K, Mohammadi A (2009): A study of natural co-infection caused by avian influenza (H9 subtype) and infection bronchitis viruses in broiler chicken farms showing respiratory signs. Online J Vet Res, $13,53-62$.

12.Ahmad, M. D., M. Chaudhry, H. B. R. Chaudhry. Detection antibodies against avian pneumovirus in broiler breeder flocks in Pakistan. Pak Vet J, 25(2): 63-66, 2005.

13. Alkhalaf, A. N. Serological survey on avian pneumovirus infection in commercial poultry farms in saudi Arabia. Pak Vet J, 30(2): 124$125,2010$.

14. Gharaibeh SM, Algharaibeh GR (2007): Serological and molecular detection of avian 
pneumovirus in chickens with respiratory disease in Jordan. Poult Sci, 86, 1677-1681.

15. Homayoufar N, Shoushtari AH, Chakhkar S, Bozorgmehri-Fard MH (2011) Detection of aMPV in chicken flocks in East and West Azerbaijan. Comp Pathobiol, 2, 965-970.

16. Rahimi M (2011): Seroprevalence of avian metapneumovirus infection in broiler and broiler breeder chickens in Iran. Vet MedCzech, 8, 395-399.

17. Chacon, J. L., P. E. Brandao, M. Buim, L. Villarreal, A. J. Ferreira. Detection by reverse transcriptase-polymerase chain reaction and molecular characterization of subtype B avian metapneumovirus isolated in Brazil. Avian Pathol, 36: 383-387, 2007.

18.Gough RE (2003): Avian Pneumoviruses. 407-465. In: Saif YM, Barnes HJ, Glisson JR, Fadly AM, McDougald LR, Swayne DE (Ed.), Diseases of Poultry. $11^{\text {th }}$ ed., Iowa State Press.

19.Banet-Noach, C., L. Simanov, S. H. Perk. Characterization of Israeli avian metapneumovirus strains in turkeys and chickens. Avian Pathol, 34: 220-226, 2005.

20.Cook, J. K. A., M. M. Ellis, M. B, Huggins. The pathogenesis of turkey rhinotracheitis virus in turkey poults inoculated with the virus alone or together with two strains of bacteria. Avian Pathol, 20: 155-166, 1991.

21.Naylor CJ, Al-Ankari A, Al-Afaleq A, Bradbury J, Jones R (1992): Exacerbation of Mycoplasma gallisepticum infection in turkeys by rhinotracheitis virus. Avian Pathol, 21, 295-305.

22.Jirjis FF, Noll SL, Halvorson DA, Nagaraja KV, Martin F, Shaw DP (2004): Effects of Bacterial Coinfection on the Pathogenesis of Avian Pneumovirus Infection in Turkeys. Avian Dis, 48, 34-49.

23. Van de Zande S, Nauwynck H, De Jonghe S, Pensaert M (1999): Comparative pathogenesis of a subtype A with a subtype B avian pneumovirus in turkeys. Avian Pathol, $28,239-244$.

24.Rubbenstroth D, Ryll M, Behr KP, Rautenschlein S (2009): Pathogenesis of Riemerella anatipestifer in turkeys after experimental mono-infection via respiratory routes or dual infection together with the avian metapneumovirus. Avian Pathol, 38, 497-507

25.Turpin EA, Perkins LEL, Swayne DE (2002): Experimental infection of turkeys with avian pneumovirus and either Newcastle disease virus or Escherichia coli. Avian Dis. 46, 412422 . 